\title{
Penggunaan Media Corong Berhitug untuk Meningkatkan Hasil Belajar Siswa Pada Mata Pelajaran Matematika di Kelas II Sekolah Dasar Negeri 37 Pekanbaru
}

\author{
Iin Gusmana ${ }^{1}$, Mimi Hariyani ${ }^{2}$ \\ ${ }^{1,2}$ Program Magister Pendidikan Madrasah Ibtidaiyah, Universitas Islam Negeri Sultan Syarif \\ Kasim Rian \\ e-mail: Iingusmana8@gmail.com
}

\begin{abstract}
ABSTRAK. This research aimed to increase of student learning achievement through the use of Corong Berhitung mediaon Mathematics subject at the second grade of State Elementary School 37 Pekanbaru, Tampan District. This research was instigated by the low of student learning achievement that could not reach the minimum standard of passing grade determined 75 . This research was a Classroom Action Research. The subjects of this research were the teachers and students, and the objects were theuse of CorongBerhitung media and learning achievement.This research was conducted for two cycles, and every cycle comprised two meetingswith several steps-planning/preparing the action, implementing, observing, and reflecting. Observation, learning achievement test, and documentation were the techniques of collecting the data. The technique of analyzing the data was Descriptive analysis that was started from obtaining, arranging, processing, presenting, and analyzing the numerical data to get the description of a symptom, event or situation.Based on the research findings, the use of CorongBerhitung media could increase student learning achievement. It was known that the mean was $55.56 \%$ before the action and it was on less than $60 \%$ interval that was on poor category. After implementing the media in the first cycle, the student learning achievement increased to $75 \%$ that was on $70 \%-79 \%$ interval and it was on enough category. In the second cycle, the student learning achievement increased to $100 \%$ that was on $90 \%-100 \%$ interval and it was on very good category. Thus, it could be concluded that the use of CorongBerhitung media could increase student learning achievementat the second grade of State Elementary School 37 Pekanbaru, Kecamatan Tampan.
\end{abstract}

Kata kunci: Media, CorongBerbitung, Learning Achievement.

\section{PENDAHULUAN}

Pendidikan diartikan sebagai usaha manusia untuk membina kepribadiannya sesuai dengan nilai-nilai di dalam masyarakat dan kebudayaan (Hasbullah, 2006:1). Pendidikan 
adalah suatu proses kedewasan untuk anak didik melalui interaksi, proses dua arah antara guru dan siswa. Secara umum belajar adalah tindakan dan prilaku siswa yang komplek. Dalam hal ini belajar berusaha untuk mengubah tingkah laku. Sehinggan tindakan belajar hanya di alami oleh siswa sendiri adalah penentu terjadinya tindakanya proses pembelajaran Jadi, belajar akan membawa suatu perubahan pada individuindividu yang belajar. (Dimiyati dkk, 2006: 107).

Perubahan tersebut tidak hanya berkaitan dengan penambahan ilmu pengetahuan, tetapi juga berbentuk keterampilan dan sikap (Sardiman, 2007 :21). Sekolah sebagai suatu lembaga pendidikan formal, secara sistematis telah merencanakan berbagai lingkungan, yakni lingkungan pendidikan yang m enyediakan berbagai kesempatan bagi siswa untuk melakukan berbagai kegiatan pembelajaran sehingga para siswa memperoleh pengalaman. Sehingga segala aspek pentingnya pentingnya mencari ilmu sebagaimana firman Allah Subhanahu Wata'ala dalam surat Al- Mujadalah ayat 11.

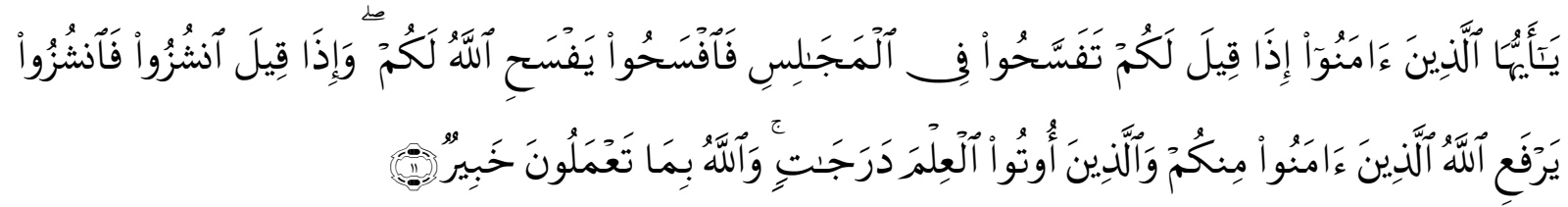

Artinya: Hai orang-orang beriman apabila dikatakan kepadamu: “ Berlapang-lapanglah dalam majlis", maka lapangkanlah niscaya Allah akan memberikan kelapangan untukmu. Dan apabila dikatakan: "Berdirilah kamu” Maka berdirilah, niscaya Allah akan meninggikan orang-orang yang beriman di antaramu dan orangorang yang diberi ilmu pengerahuan beberapa derajat. Dan Allah Maha Mengetahui apa yang kamu kerjakan. (Q.S Al-Mujadalah: 11)

Proses pembelajaran dapat mewujudkan tujuan pendidikan salah satu cara adalah dengan proses pembelajaran disekolah. Pembelajaran adalah proses dimana terjadi kegiatan belajar dan mengajar. Mengajar merupakan suatu usaha untuk menciptakan kondisi atau sistem lingkungan yang mendukung dan memungkinkan untuk berlangsungnya proses belajar. Sedangkan belajar adalah suatu proses yang dilakukan individu untuk memperoleh suatu perubahan tingkah laku yang baru secara keseluruhan, sebagian hasil pengalaman individu itu sendiri didalam interaksi dengan lingkungannya. Dalam proses pembelajaran guru berupaya mengubah masukan berupa siswa yang belum terdidik menjadi siswa yang terdidik, siswa yang belum memiliki pengetahuan tentang sesuatu, menjadi siswa yang memilki pengetahuan. Demikian pula siswa yang memiliki sikap, kebiasaan atau tingkah laku yang belum mencerminkan eksistensi dirinya sebagai pribadi baik, menjadi siswa yang memiliki sikap, kebiasaan dan tingkah laku baik. Jadi pembelajaran adalah suatu aktivitas yang dengan sengaja untuk 
memodifikasi berbagai kondisi yang diarahkan untuk tercapainya suatu tujuan yaitu terjadinya tujuan kurikulum (Mardiah Hayati, 2014 : 12-13).

Matematika merupakan salah satu pelajaran yang wajib ada di sekolah mulai dari tingkat sekolah dasar hingga perguruan tinggi. (Mimi dan Melly, 2013 : 9). Matematika merupakan salah satu bidang studi yang diajarkan di SD atau MI. Seorang guru SD atau MI yang akan mengajarkan matematika kepada siswanya, hendaklah mengetahui dan memahami objek yang akan diajarkannya, yaitu matematika. Matematika adalah salah satu disiplin ilmu yang diperlukan dalam kehidupan sehari-hari. Keuntungan apabila siswa belajar aktif adalah tanggapan dari sesuatu atau yang di kerjakan sendiri lebih sempurna, mudah direproduksi, dan pengertian yang diperoleh lebih jelas, setelah itu beberapa sifat watak terpimpin dapat dipupuk misalnya: hati-hati, rajin , tekun, tahan diuji, percaya pada diri sendiri, perasaan sosial dan sebagainya (Ramayulis, 1990 : 90 ).

Matematika merupakan ilmu yang mempelajari hubungan pola, bentuk dan struktur (Mimi dan Melly, 2013 : 1). Matematika berarti ilmu pengetahuan yang di dapat dengan berfikir atau bernalar matematikalebuh menekankan kegiatan dalam rasio atau penalaran. Dengan demikian mata pelajaran matematika adalah pelajaran yang sangat penting dipelajari di tingkat SD / MI bertujuan untuk mebekali siswa untuk bisa berfikir secara logis, analisis dan kreatif, serta kemampuan bekerja sama untuk masalah dengan dalam kegiatan sehari-sehari.

Sebelum peneliti menerapkan media corong berhitung ternyata guru matematika kelas II belum pernah menggunakan media corong berhitung. Berdasarkan kenyataan yang dijumpai di kelas II Sekolah Dasar Negeri 37 Pekanbaru Kecamatan Tampan dimana kelas II terbagi menjadi 4 (empat) kelas yaitu kelas IIa, IIb, IIc, dan IId. Peneliti memilih kelas IIc yang akan dilakukan penelitian tindakan kelas dengan menggunakan Media Corong Berhitung Hasil observasi dan wawancara peneliti dengan guru kelas II pada tanggal 06 Maret yang lalu yaitu ibu Isroyani, S.Pd. Dimana beliau mengatakan bahwa hasil belajar siswa yang masih tergolong rendah 44,44\% yang belum mencapai KKM dikarenakan guru yang bersangkutan sudah berupaya memaksimalkan, mungkin dengan melakukan kegiatan belajar yang monoton sebagaimana halnya yang dilakukan oleh guru seperti ceramah, tanya jawab berhitung dengan cempoa, guru kurang menggunakan media dalam proses belajar.

Berdasarkan masalah tersebut peneliti menemukan gejala-gejala yang menunjukkan hasil belajar siswa dalam proses pembelajaran masih tergolong rendah pada mata pelajaran Matematika yaitu sebagai berikut: (1) dari 36 orang siswa hanya 20 orang siswa atau 55,56\% yang telah mencapai nilai KKM yang telah ditetapkan, KKM mata pelajaran Matematika di SD tersebut adalah 75. (2) dari 36 orang siswa ada 16 orang siswa atau 44,44\% siswa masih sulit dalam menjawab soal ulangan dengan benar. (3) 
Setiap kali diberi tugas rumah, sekitar 7 orang siswa atau 19,44\% masih memperoleh nilai yang rendah.

Berdasarkan latar belakang di atas, maka penelitian tertarik ingin melakukan suatu penelitian tindakan kelas sebagai upaya perbaikan terdapat hasil belajar pembelajaran Matematika dengen judul: Penggunaan Media Corong Berhitung untuk Meningkatkan Hasil Belajar Siswa pada Mata Pelajaran Matematika Kelas II Sekolah Dasar Negeri 37 Pekanbaru Kecamatan Tampan.

Tujuan dari penelitian ini adalah untuk mengetahui apakah Penggunaan Media Corong Berhitung untuk Meningkatkan Hasil Belajar Siswa pada Mata Pelajaran Matematika Kelas II Sekolah Dasar Negeri 37 Pekanbaru Kecamatan Tampan Pada pokok bahasan Operasi Hitung Perkalian dan Pembagian. 


\section{METODOLOGI}

Penelitian ini adalah penelitian tindakan kelas. Penelitian dilaksanakan di kelas II Sekolah Dasar Negeri 37 Pekanbaru, pada semester dua. Adapun waktu penelitian pada bulan Februari tahun ajaran 2016/2017. Subjek dalam penelitian ini adalah siswa kelas II Sekolah Dasar Negeri 37 Pekanbaru dengan jumlah siswa 36 orang, yang mana terdiri dari 17 siswa laki-laki dan 19 siswa perempuan. Sedangkan yang menjadi objek dalam penelitian ini adalah meningkatkan hasil belajar siswa pada mata pelajaran Matematika dengan menggunakan Media Corong Berhitung di kelas II Sekolah Dasar Negeri 37 Pekanbaru. Penelitian yang dilaksanakan adalah Penelitian Tindakan Kelas. Penelitian tindakan kelas adalah suatu bentuk penelitian yang bersifat reklektif dengan melakukan tindakan-tindakan melakukan tindakan- tindakan tertentu agar dapat memperbaiki atau meningkatkan praktik-praktik pembelajaran di kelas secara profesional (Masnur Muslich, 2011 : 9).

Langkah-langkah penelitian ini terdiri dari perencanaan tindakan, pelaksanaan tindakan, observasi dan refleksi Dalam tahap perencanaan atau persiapan tindakan ini, langkah-langkah yang dilakukan adalah sebagai berikut: (a) Menyusun Silabus yang berisi standar kompontensi, kompotensi dasar, indikator,materi pokok,kegiatan pembelajaran yang menggunakan media corong berhitung, alokasi waktu,sumber belajar dan penilaian. (b) Rencana Pelaksanaan Pembelajaran (RPP) yang berisi standar kompotensi, kompotensi dasar, indikator, tujuan pembelajaran, materi pokok, metode pembelajaran, langkahlangkah pembelajaran, sumber belajar, dan penilaian (c) Membuat media corong berhitung (d) Menyusun soal ulangan setiap siklus untuk mengetahui hasil belajar siswa (e) Membuat lembar observasi aktivitas Guru dan siswa selama proses pembelajaran dengan penggunaan media corong berhitung. (f) Meminta kesediaan guru kelas menjadi observer.

Teknik pengumpulan data yang digunakan dalam penelitian ini adalah obaervasi, tes tertulis, dan dokumentasi. Metode observasi dilakukan untuk mengetahui bagaimana pembelajaran matematika yang berlangsung di kelas. Tes tertulis dilakukan untuk mengetahui seberapa fahamnya siswa dalam pelajaran matematika dengan mnggunakan model pembelajaran student facilitator and explaining. Dokumentasi ini dilakukan untuk mengetahui sejarah sekolah, keadaan guru dan siswa, sarana dan prasarana yang ada di Sekolah Dasar Negeri 37 Pekanbaru Kecamatan Tampan dan data tentang hasil belajar siswa.

Teknik analiasis lembar observasi penelitian ini adalah dengan menggunakan teknik analisis deskriptif. Teknik statistik deskriptif merupakan kegiatan statistik yang dimulai dari menghimpun data, menyusun atau mengukur data, mengelola data, menyajikan dan menganalisis data angka guna memberikan gambaran suatu gejala, peristiwa atau keadaan. Analisis deskriptif ini dilakukan untuk mengetahui gambaran data yang akan dianalisis. (a) Analisis data kualitatif, yaitu data yang berupa informasi yang berbentuk kalimat yang memberi gambaran tentang ekspresi siswa berkaitan dengan tingkat pemahaman terhadap 
suatu mata pelajaran, pandangan atau sikap siswa terhadap teknik belajar yang baru, aktivitas siswa mengikuti pelajaran, perhatian, antusias dalam belajar dan kepercayaan diri dapat dianalisis secara kualitatif. (b) Analisis data kuantitatif, yaitu data yang berupa angka (nilai skor) dapat dianalisis secara deskriptif. Misalnya mencari nilai rata-rata persentase keberhasilan, dan lain-lain (Kunandar, 2008 : 127).

Selain itu analisis deskriptif juga digunakan (Anas Sujiono, 2004 : 43) untuk menentukan keberhasilan aktivitas guru dan aktivitas siswa dalam bentuk mendemonstrasikan kegiatan selama proses pembelajaran diolah dengan menggunakan rumus presentase yaitu sebagai berikut:

Keterangan :

$$
\begin{array}{ll}
\mathrm{P} & =\text { Angka Persentase Aktivitas Guru } \\
\mathrm{F} & =\text { Frekuensi Aktivitas Guru } \\
\mathrm{N} & =\text { Angka Persentase } \\
100 \% & =\text { Bilangan tetap }
\end{array}
$$

\section{HASIL DAN PEMBAHASAN}

\section{Hasil Penelitian}

Diketahui bahwa pada siklus I (pertemuan pertama dan kedua) aktivitas guru tergolong "Sangat Sempurna", dengan persentase 98,44\% berada pada rentang 90-100 Pada siklus II (pertemuan ketiga dan keempat) tetap menjadi 94,44\% tergolong "Sangat Sempurna", berada pada rentang 90-100 lebih jelas dapat dilihat pada tabel berikut ini: 
Tabel 1. Rekapitulasi Aktivitas Guru Siklus I Dan Siklus II

\begin{tabular}{ccccccc}
\hline $\begin{array}{c}\text { Aspek } \\
\text { Yang } \\
\text { Diamati }\end{array}$ & $\begin{array}{c}\text { Pertemuan } \\
\mathbf{1}\end{array}$ & $\begin{array}{c}\text { Pertemuan } \\
\mathbf{2}\end{array}$ & $\begin{array}{c}\text { Rata- } \\
\text { rata }\end{array}$ & $\begin{array}{c}\text { Pertemuan } \\
\mathbf{3}\end{array}$ & $\begin{array}{c}\text { Siklemuan } \\
\mathbf{4}\end{array}$ & $\begin{array}{c}\text { Rata- } \\
\text { rata }\end{array}$ \\
\hline $\begin{array}{c}\text { Aktivitas } \\
\text { Guru }\end{array}$ & $96,88 \%$ & $100 \%$ & $98,44 \%$ & $96,87 \%$ & $100 \%$ & $98,44 \%$ \\
\hline
\end{tabular}

Perbandingan persentase aktivitas guru dengan penggunaan media corong berhitung pada siklus I dan siklus II juga dapat dilihat pada histogram berikut:

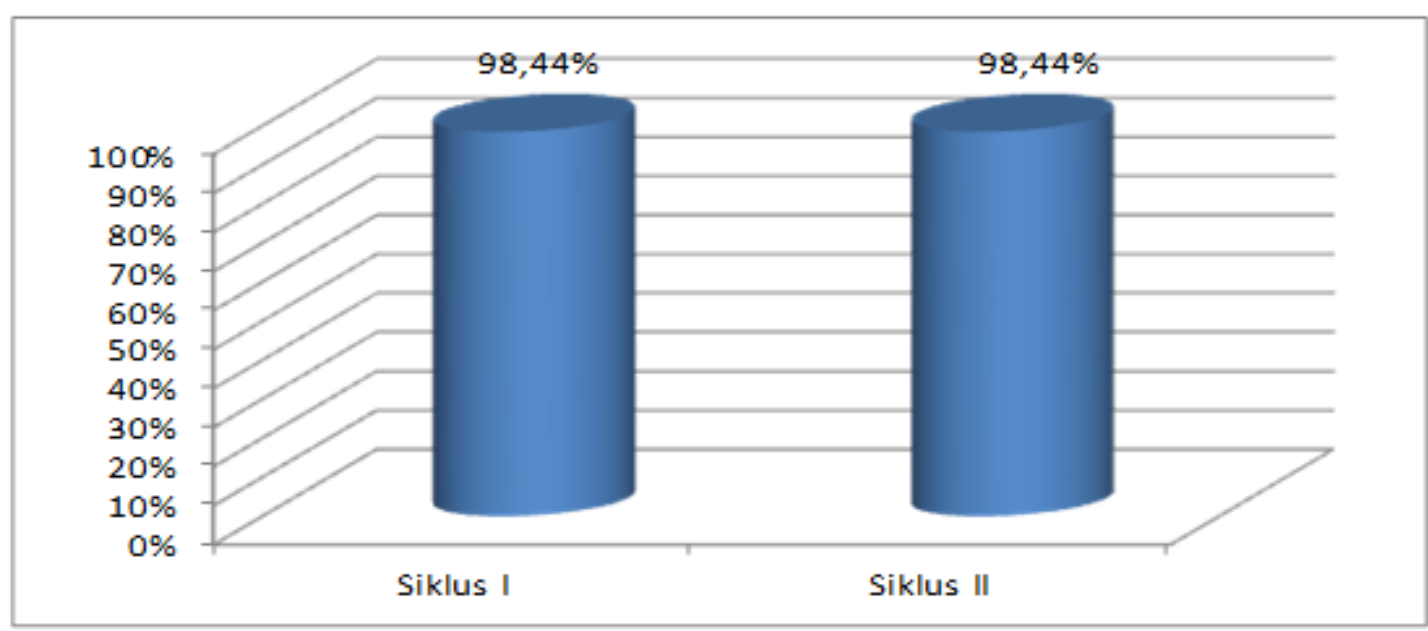

\section{Gambar 1.Grafik Rekapitulasi Perbandingan Aktivitas Guru Pada Siklus I (Pertemuan Pertama dan kedua) dan Siklus II (Pertemuan Ketiga dan Keempat}

\section{Aktivitas Siswa}

Persentase aktivitas siswa selama kegiatan belajar mengajar dengan menggunakan media corong berhitung pada pertemuan pertama siklus I presentase aktivitas siswa secara klasikal memperoleh 98,26\% dengan rentang nilai 76-100 tergolong "Baik", pada pertemuan kedua siklus I presentase aktivitas siswa memperoleh 98,43\% dengan rentang nilai 76-100 tergolong "Baik", sedangkan pada pertemuan ketiga siklus II terjadi peningkatan sebesar 98,30\% dengan rentan nilai 76- 100 tergolong "Baik", pada perteuan keempat siklus II persentase mencapai 98,43\% dengan rentang nilai 76-100 tergolong “ Baik". 
Tabel 2. Rekapitulasi Aktivitas Siswa Pada Siklus I dan Siklus

II

\begin{tabular}{|c|c|c|c|c|c|c|}
\hline \multirow{2}{*}{$\begin{array}{l}\text { Aspek } \\
\text { Yang } \\
\text { Diamati }\end{array}$} & \multicolumn{3}{|c|}{ Sikdus I } & \multicolumn{3}{|c|}{ Sildus II } \\
\hline & $\begin{array}{c}\text { pertemuan } \\
1\end{array}$ & $\begin{array}{c}\text { Pertemuan } \\
2\end{array}$ & $\begin{array}{c}\text { Rata- } \\
\text { rata }\end{array}$ & $\frac{\text { Pertemuan }}{3}$ & $\frac{\text { Pertemuan }}{4}$ & $\begin{array}{l}\text { Rata- } \\
\text { rata }\end{array}$ \\
\hline $\begin{array}{c}\text { Aktivitas } \\
\text { Siswa }\end{array}$ & $97,92 \%$ & $98,6 \%$ & $98,26 \%$ & $98,3 \%$ & $98,6 \%$ & $98,43 \%$ \\
\hline
\end{tabular}

\section{Sumber. Data Hasil Olahan Penelitian, Tahun 2017}

Perbandingan aktivitas siswa pada siklus I dan siklus II pada tiap pertemuan juga dapat dilihat pada histogram berikut:

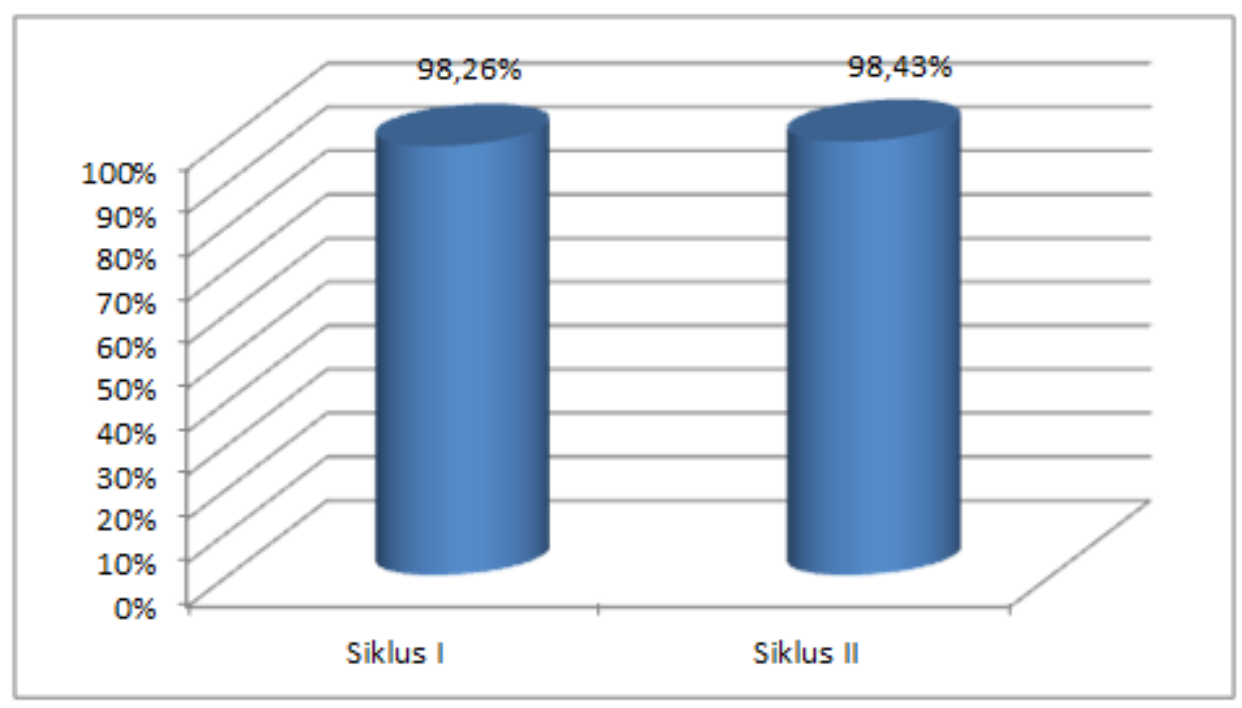

Gambar 3. Grafik Rekapitulasi Perbandingan Aktivitas Siswa pada Siklus I (Pertemuan Pertama dan kedua) dan Siklus II (Pertemuan Ketiga dan Keempat)

Hasil Belajar

Perbandingan hasil belajar siswa dilihat dari sebelum tindakan, siklus I dan siklus II secara jelas dapat dilihat pada tabel berikut:

Tabel 3.Rekapitulasi Hasil Belajar Siswa dari Sebelum Tindakan, Siklus I dan Siklus II

\begin{tabular}{|c|c|c|c|c|}
\hline & Tes & $\begin{array}{ll} & \text { JumlahSi } \\
\text { swa } & \\
\end{array}$ & $\begin{array}{r}\text { Jumlah Siswa Yang } \\
\text { Tuntas }\end{array}$ & $\begin{array}{r}\text { Jumlah Siswa } \\
\text { Yang Tidak Tuntas }\end{array}$ \\
\hline \multirow{3}{*}{ kan } & SebelumTinda & 36 & $20 / 55,56 \%$ & $16 / 44,44 \%$ \\
\hline & Siklus I & 36 & $27 / 75 \%$ & $9 / 25 \%$ \\
\hline & Siklus II & 36 & $36 / 100 \%$ & $0 / 0 \%$ \\
\hline
\end{tabular}

El-Ibtidaiy: Journal of Primary Education, Vol. 3, No. 2, Oktober 2020, Hal 124-134 
Berdasarkan Tabel IV.23, pada sebelum tindakan siswa yang tuntas secara keseluruhan adalah 16 orang siswa atau dengan persentase 44,44\%, pada siklus I siswa yang tuntas secara keseluruhan meningkat menjadi 27 orang siswa atau dengan persentase

$75 \%$, dan pada siklus II siswa yang tuntas secara keseluruhan adalah 36 orang siswa atau dengan persentase 100\%. Perbandingan hasil belajar siswa dari sebelum tindakan, siklus I, dan siklus II juga dapat dilihat pada gambar berikut:

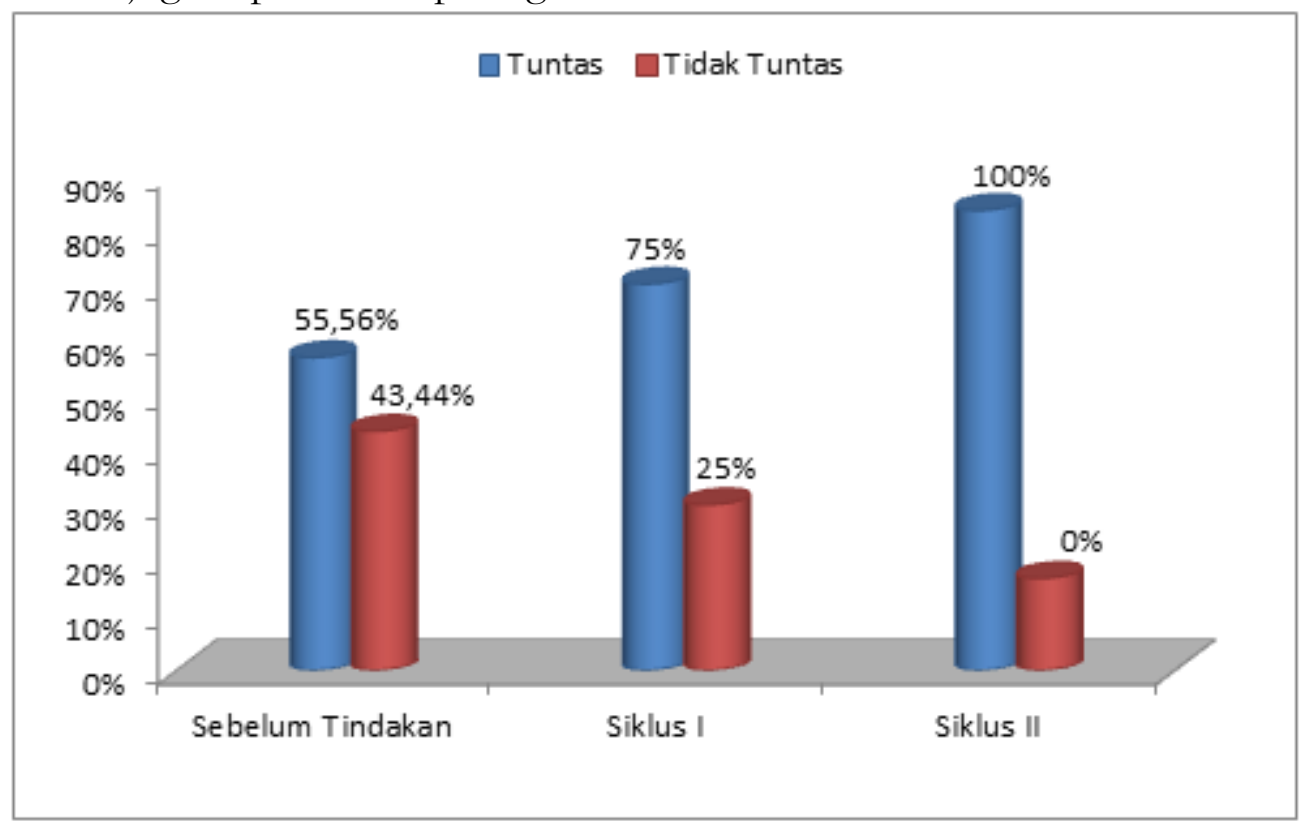

\section{Gambar 4. Grafik Rekapitulasi Perbandingan Hasil Belajar Siswa Sebelum Tindakan Siklus I dan Siklus II}

Berdasarkan hasil penelitian yang peneliti lakukan, bahwa penelitian hasil belajar siswa pada mata pelajaran matematika meningkat dari sebelum tindakan 44,44\%, Siklus I $75 \%$, dan Siklus II 100\%. Jadi, penggunaan media corong berhitung sangat perlu dilakukan karena penggunaan media corong berhitun dapat meningkatkan hasil belajar siswa.

\section{KESIMPULAN}

\section{Simpulan}

Berdasarkan hasil penelitian ini dapat disimpulkan bahwa penggunaan media corong berhitung dapat meningkatkan hasil belajar siswa kelas II pada mata pelajaran Matematika di Sekolah Dasar Negeri 37 Pekanbaru. Hal ini dapat dilihat bahwa hasil belajar Matematika siswa sebelum tindakan hanya mencapai 44,44\% atau tergolong" Sangat Kurang”. Setelah dilakukan tindakan kelas pada siklus I, hasil belajar siswa meningkat menjadi 75\% atau tergolong "Cukup". Sedangkan pada siklus II terjadi peningkatan $132 \mid$ 
menjadi $100 \%$ atau tergolong "Sangat Baik". Artinya indikator keberhasilan yang telah ditetapkan yaitu 75\% telah tercapai.

\section{Saran}

Dapat disimpulkan bahwa penggunaan media corong berhitung Bertolak dari pembahasan hasil penelitian dan kesimpulan (1) Melalui media corong berhitung guru berharapdari 36 orang siswahanya 20 orang siswa atau 55,55\% yang telah mencapai nilai KKM yang ditetapkanyaitu 75. (2) Melalui media corong berhitung guru berharap dari 36 orang siswa ada 16 siswa atau 44,44\% siswa masih sulitt dalam menjawab soal-soal yang benar. (3) Dari 36 orang siswahanya orang siswa atau 19,44\% yang mengajukan pertanyaan ketika diberikan kesempatan untuk bertanya oleh guru. Setelahditerapkan model pembelajaran student facilitator and explaining guru berharapbanyaksiswa yang mengajukanpertanyaan.

\section{REFERENSI}

Alex Sobur. 2003. Psikologi Umum. Bandung: CV Pustaka Setia.

Anas Sudjino. 2004. Pengantar Statistik Pendidikan. Jakarta: Raja Grafindo Persada.

Aunurrahman. 2009. Belajar dan Pembelajaran. Bandung: Alfabeta.

BSNP. 2007. Pedoman Penilaian Hasil Belajar di Sekolah Dasar. Jakarta: Depdiknas.

Depdiknas 2004. Rambu-rambu Penetapan Ketuntasan Belajar Minimum dan Analisis Hasil Pencapaian Standar Ketuntasan Belajar. Jakarta: Pusat Kurikulum Balitbang Depdiknas.

E. Mulyasa. 2011. Kurikulum Tingkat Satuan Pendidikan. Bandung Remaja Rosdakarya.

Istarani. 2014. 58 Model Pembelajaran Inovatif. Medan: Media Perkasa.

Mardia Hayati. 2014. Desain Pembelajaran. Pekanbaru: CV Mutiara Pesisir Sumatra.

Masnur Muslich. 2011. Melaksanakan Penelitian Tindakan Kelas Itu Mudah. Jakarta: Bumi Aksara.

Mimi Hariyani \& Melly Andriyani. 2013.Pembelajaran Matematika SD/MI. Pekanbaru: Benteng Media.

Mubibbinsyah. 2013. Psikologi Pendidikan. Bandung: PT. Remaja Rosdakarya.

Ngalim Purwanto. 1987. Psikologi Pendidikan. Bandung: Remaja Rosdakarya. Oemar Hamalik. 2005. Kurikulum dan Pembelajaran. PT. Bumi Aksara. Purwanto. (2013). Evaluasi Hasil Belajar. Yogyakarta: Pustaka Belajar. Ramayulis. (1990). Pengajaran Matematika SD. Jakarta: Kalam Mulia. 
Sardiman. 2007. Interaksi dan Motivasi Belajar Mengajar. Jakarta: Raja Grafindo Persada.

Suharsimi Arikunto. 2006. Prosedur Penelitian Suatu Pendekatan Praktek. Jakarta: Rineka Cipta. 